Relato de Caso | Case Report

\title{
Bilateral lineal endotheliitis: case report
}

\author{
Endotelite linear bilateral: relato de caso
}

Liliana Moreno Garcia ${ }^{1}$, Mauricio Vélez Fernandez ${ }^{2}$

\begin{abstract}
To report the case of a patient with bilateral herpetic lineal endotheliitis successfully treated with topic steroids and systemic antiviral. 17 year old female with blurred vision, at evaluation localized edema was observed on both corneas associated to Descemet folds and a line of pigmented precipitates. Topic prednisolone and oral acyclovir are initiated with complete resolution of signs and symptoms. Lineal endotheliitis is produced as an answer of endotelial cells to viral infection; maybe due to an immune reaction against some antigens from herpes virus family. It has the potential of relapses even in the absence of viral replication, with secondary untreatable stromal edema. It responds well to antiviral and steroids treatment, although, on those patients who don't improve, is necesary to make additional tests.
\end{abstract}

Keywords: Endothelium, corneal; Simplexvirus; Corneal edema/drug therapy; Prednisolone/therapeutic use; Acyclovir/therapeutic use; Humans; Male; Adolescent

\section{RESUMO}

Relatar o caso de uma paciente com endotelite linear herpética bilateral tratado com sucesso por meio de corticoides tópicos e antivirais sistêmicos. Paciente do sexo feminino, 17 anos de idade, com a visão turva, na avaliação foi observado edema localizado em ambas as córneas associadas a dobras de Descemet e uma linha de precipitados ceráticos pigmentados. Prednisolona tópica e aciclovir oralforam utilizados com resolução completa dos sinais e sintomas. A endotelite linear é uma resposta das células endoteliais à infecção viral, talvez devido a uma reação imunológica contra alguns antígenos do vírus da familia do herpes. Tem o potencial de recidiva mesmo na ausência de replicação viral, com edema estromal secundário intratável. Ela responde bem ao tratamento antiviral e esteroides, embora, em pacientes que não melhoram, é necessária a realização de testes adicionais.

Descritores: Epitélio posterior; Simplexvirus; Edema da córnea/quimioterapia: Prednisolona/uso terapéutico; Aciclovir/uso terapéutico; Humanos; Feminino; Adolescente

\section{INTRODUCTION}

Corneal endothelium inflammation is known as endotheliitis, and the lineal type is believed as caused by virus from the family Herpesviridae such as Herpes simplex, Citomegalovirus and Varicella zoster virus. It was first described in 1985 by Robin in a patient with intraocular inflammation associated with Herpes simplex infection and progressive endotheliitis with a line of keratic precipitates ${ }^{(1)}$. There are reports of some idiopathic or autoimmune forms of endotheliitis in which they failed in detecting the virus as responsible cause, that's why some authors believed this was immunologically mediated or presumed autoimmune ${ }^{(2-4)}$. The involvement of corneal endothelium secondary to Herpes simplex infection is classified in lineal, diffuse and disciform based on the distribution of keratic precipitates and the configuration of the overlying stromal and epithelial edema. The lineal form is clinically seen as localized progressive corneal edema from the periphery to the center along with a line of keratic precipitates and associated with mild inflammatory anterior chamber reaction ${ }^{(3)}$. The successful treatment with topic or systemic antiviral and steroids has been reported ${ }^{(2,4-6)}$

Recurrences are associated with lost of endothelial cells that can generate permanent and irreversible corneal edema.

\section{CASE REPORT}

Here we report the case of a 17 year old female patient, immunocompetent, from Apartadó (located at Northeast of Colombia).
She consulted at cornea service after presenting ten days of blurred vision in both eyes; this was the first episode, associated to redness, photophobia and mild ocular pain. No history of systemic disease was recorded, only previous mild contusive trauma on right eye two months ago without consequences. Currently is not under systemic or topic treatment. Clinical exam reveals visual acuity by right eye counting fingers and left eye 20/100 with Snellen chart. We could observe in both eyes corneal edema localized at superior two thirds (Figure 1), Descemet's membrane folds along with a line of pigmented keratic precipitates at the border of the edema, and details of anterior chamber reaction could not be noted because of the opacity (Figure 2); there was not epithelial defect identified or marks of an old dendritic keratitis. Intraocular pressure (IOP) was measured at $12 \mathrm{mmHg}$ on both eyes. The rest of the exam was normal.

With the clinical suspect of lineal endotheliitis, we decided to initiate treatment with oral acyclovir 400 mg, five times per day, and prednisolona 1\%, every 4 hours in both eyes. Serologic analysis for immunoglobulins $\mathrm{G}$ and $\mathrm{M}$ of Herpes simplex virus (HSV), cytomegalovirus (CMV), Human Immunodeficiency virus (HIV) and endothelial count were requested. After first week of treatment, the patient manifested improvement in symptoms and in vision; we could document visual acuity (VA) of 20/20 in right eye and 20/25 in left eye and the corneal edema was absent, in endothelium remained few pigmented precipitates and mild anterior chamber reaction (Figure 3). Unfortunately the patient could not make her blood tests, but because of the good clinical response, we decided
Submitted for publication: April 27, 2013

Accepted for publication: May 24, 2013

Study carried out at Universidad Pontificia Bolivariana, Medellín, Colombia.

${ }^{1}$ Ophthalmology Resident, Universidad Pontificia Bolivariana, Medellín.

2 Ophthalmologist - Cornea, profesor, Universidad Pontificia Bolivariana, Medellín.
Funding: No specific financial support was available for this study.

Disclosure of potential conflicts of interest: L.M.Garcia, None; M.V.Fernandez None.

Correspondence address: Liliana Moreno García. Transversal 38 \# 72-148, Apto. 201 - Edificio Torre Lujo. Medellín (Antioquia), Colombia - E-mail: lilymon9@hotmail.com 
to continue oral acyclovir until two weeks were completed and taper of steroids.

\section{DISCUSSION}

We perform a search on data bases of lineal endotheliitis. There are various mechanisms of ocular disease associated to HSV infection including direct cell damage of live viruses, immune and inflammatory mechanisms or structural damage. On the spectrum of herpetic corneal infection, endothelial involvement is classified according to the configuration of stromal and epithelial secondary edema and the distribution of the keratic precipitates in disciform, difuse or

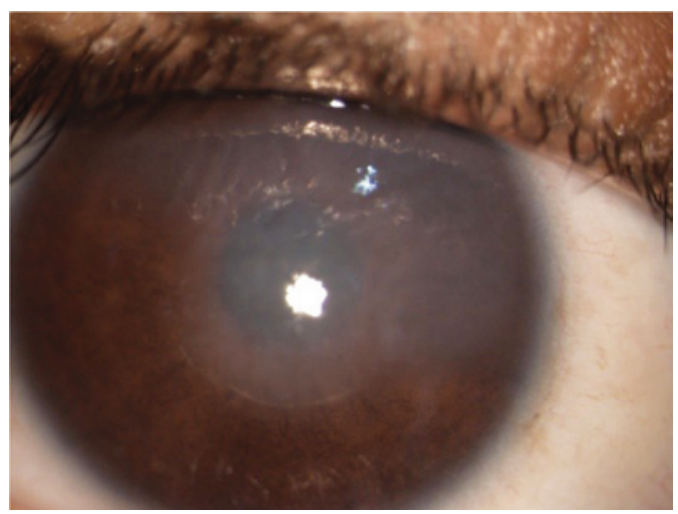

Figure 1. Right eye with stromal edema and Descemet folds over keratic precipitates.

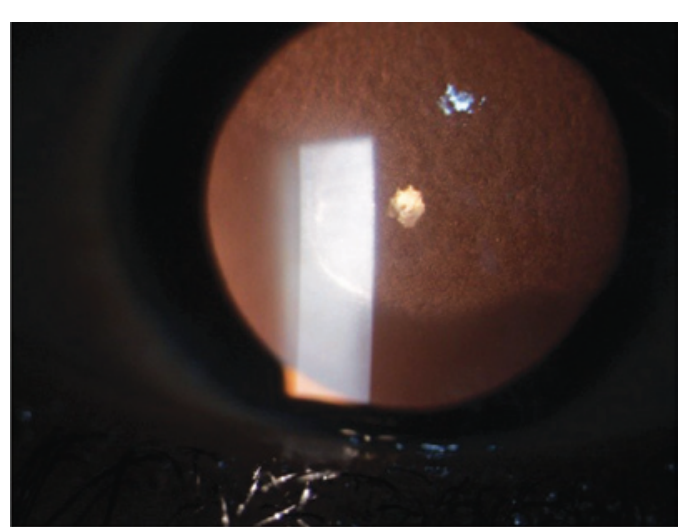

Figure 2. Right eye in retroillumination, keratic precipitates can be observed.

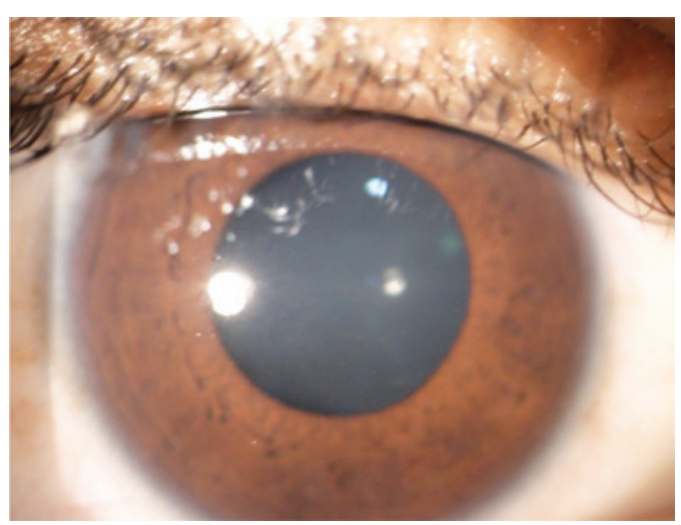

Figure 3. Right eye after one week of treatment. lineal. Clinical manifestation of endotheliitis includes ocular pain, photophobia, conjunctival injection, visual compromise and often there is not history of previous infectious epithelial keratitis ${ }^{(3)}$. Most common form of presentation is disciform that usually is central; the difuse is harder to treat for poor response to standard management and finally the lineal is characterized for localized stromal edema that initiates in the corneal periphery and advances towards the center, associated to a line of keratic precipitates delimitating the edema, it might be circumferential or sectorial reminding the reject line after corneal transplant described by Khodadoust ${ }^{(2)}$. In some cases can be observed satellite lesions of keratic precipitates organized in nummular forms (coin) outside the line of precipitates and have been related to CMV infection ${ }^{(4-6)}$; also some times the IOP could rise in an intermittent way. It has been described bilateral compromise in the third part of patients and mostly found the HSV as causal agent in these cases ${ }^{(1)}$.

Statements in favor of endothelium being the site of inflammation and no the stroma, are the fact that the only stromal finding is edema located over the damaged endothelium delineated with pigmented precipitates, and stromal infiltration and neovascularization signs of stromal inflammation are notably absent; a consequence of this chronic inflammation are the lost of endothelial cells and untreatable corneal edema ${ }^{(3)}$.

Pathophysiology that explains the direct effect on the endothelium and therefore clinical symptoms has been studied. In 1985 Robin et al., isolated for the first time HSV from a sample of aqueous humor of a patient with progressive endotheliitis ${ }^{(1)}$. Latter there were reports of various cases where HSV, CMV, varicella zoster virus (VZV) were found by polymerase chain reaction from aqueous humor from immunocompetent and immunosupressed patients with characteristics similar to lineal endotheliitis (5-8).

In cases in which etiology agent could not be found have been attributed to a immune mediated reaction, some have associated it to connective tissue diseases as lupus, scleroderma, and Sjogren syndrome ${ }^{(2,7)}$. Some observations that support this hypothesis are the similitude of the precipitates line found on this entity and the endothelial rejection line seen on penetrating keratoplasty, also the fact that steroids are essential for the success of the treatment. Experimental models have shown the presence of an "anterior-chamber associated immune deviation (ACAID)" that refers to a relative diminished or suppression of cell mediated immune response, but the humoral response intact. The anterior chamber of rabbits was sensitized with inactivated virus, thereafter live virus were inoculated and local edema associated to endothelial precipitates and mild anterior chamber reaction were observed. It is presumed that once exists a latent infection and this is intermittently activated, a variable charge of live virus reach the anterior chamber and develop a reaction against viral antigens, endothelium infection happens when previous formed antibodies are unable to neutralize live virus. This phenomenon shares characteristics with Posner Scholssman syndrome associated with HSV infection in which the primary site of infection is the trabeculum or as Fuch's heterochromic iridociclitis(4). Corneal edema progression from limbary periphery to the center, as in lineal endotheliitis, might be related with viral activation of the virus located on the trabeculum or ciliary body ${ }^{(5)}$.

Diagnosis usually is made by the presence of specific clinical signs but sometimes is necessary to make analysis from samples. Corneal biopsy taken previous to keratoplasty would be needed to make sure about the presence of the virus in endothelium, but this is not possible in most of cases and would not be practical. Polymerase chain reaction (PCR) of aqueous samples is a very important tool, however, it takes some difficulties related to de little volume extracted from anterior chamber, and this affects the manipulation of the sample. In vivo confocal microscopy findings have revealed the presence of cells that resemble the characteristic owl's eye (acidophilic intranuclear inclusion bodies) related to HSV infection ${ }^{(4)}$. 
Oral acyclovir has been reported as treatment given 200-800 mg five times a day and in cases of CMV infection, gancyclovir has been used. Steroids as oral prednisolona, associated to the antiviral, have been given $60 \mathrm{mg}$ daily with gradual tapering according to clinical answer. Topical steroids have been used as well. Variable visual outcomes have been reported even with aggressive treatment, it could be associated to endothelial lost secondary to inflammatory recurrences ${ }^{(4-8)}$.

On this case, the patient did not count with personal history of connective tissue diseases, nor previous history of presumed infective keratitis. Clinical presentation and dramatic response to treatment suggest clearly viral etiology, very probable by HSV, because of the bilateral involvement on an immunocompetent patient. The primary cause of this kerato-uveitis in absence of epithelial defect or history of this is unknown, however we can not dismiss the possible presence of live virus in ocular tissues after an asymptomatic primo infection, that has been reported in literature ${ }^{(3)}$. We consider that in our case, additional studies as PCR of aqueous humor, would not be justified because the procedure to take that samples require ocular puncture with all the risks it takes, and the clinical response was adequate after only one week after initiation. Here we report the first episode on this patient, and maybe that is why the visual outcomes where the best with the standard treatment. Is reasonable to observe the patient in time for the possibility of recurrences and progressive endothelial lost with not so good response to subsequent treatment.
Lineal endotheliitis is a corneal endothelial cell response to viral infection and can be associated to immune reaction. It has the potential of recurrences even without viral replication, loss of endothelial cells and secondary vision decrease. It has clinical response to oral acyclovir and topic steroids treatment; in those patients, who could not get adequate response is indicated to take additional exams like aqueous humor PCR to make a precise diagnosis and start oriented therapy. Serologic tests for CMV, HIV, and HSV should be made as part of the complete study of the patient and don't discard the immune role.

\section{REFERENCES}

1. Robin JB, Steigner JB, Kaufman HE. Progressive herpetic corneal endotheliitis. Am J Ophthalmol. 1985;100(2):336-7.

2. Hori Y, Maeda N, Kosaki R, Inoue T, Tano Y. Three cases of idiopathic 'multiple-parallelline' endotheliitis. Cornea. 2008; 27(1):103-6.

3. Holland EJ, Schwartz GS. Classification of herpes simplex virus keratitis. Cornea. 1999; 18(2):144-54.

4. Suzuki T, Ohashi Y. Corneal endotheliitis. Semin Ophthalmol. 2008:23(4):235-40.

5. Koizumi N, Suzuki T, Uno T, Chihara H, Shiraishi A, Hara Y, et al. Cytomegalovirus as an etiologic factor in corneal endotheliitis. Ophthalmology. 2008;115(2):292-7.

6. Koizumi N, Yamasaki K, Kawasaki S, Sotozono C, Inatomi T, Mochida C, et al. Cytomegalovirus in aqueous humor from an eye with corneal endotheliitis. Am J Ophthalmol. 2006; 141(3):564-5.

7. Shen YC, Wang CY, Chen YC, Lee YF. Progressive herpetic linear endotheliitis. Cornea. 2007; $26(3): 365-7$

8. Hwang YS, Hsiao CH, Tan HY, Chen KJ, Chen TL, Lai CC. Corneal endotheliitis. Ophthalmology. 2009;116(1):164.

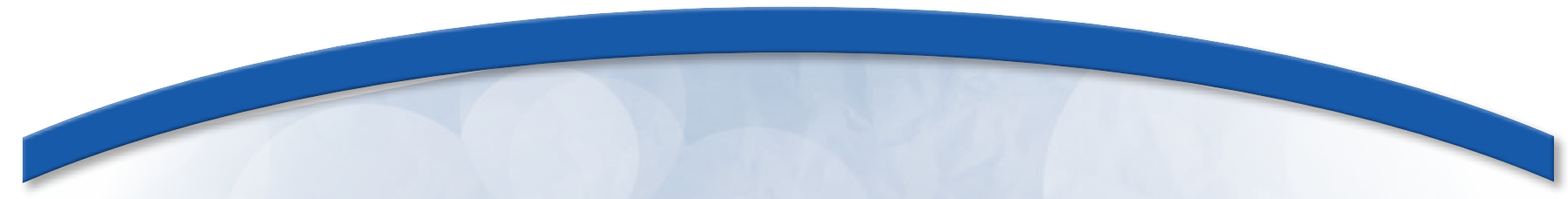

\title{
$16^{\circ}$ Congresso de Oftalmologia USP e $15^{\circ}$ Congresso de Auxiliar de Oftalmologia
}

\section{9 e 30 de novembro de 2013}

\author{
Centro de Convenções Rebouças
}

São Paulo (SP)

\section{Informações:}

Secretaria Executiva

Organização de Eventos JDE

Tels.: (11) 5082-3030 / 5084-9174

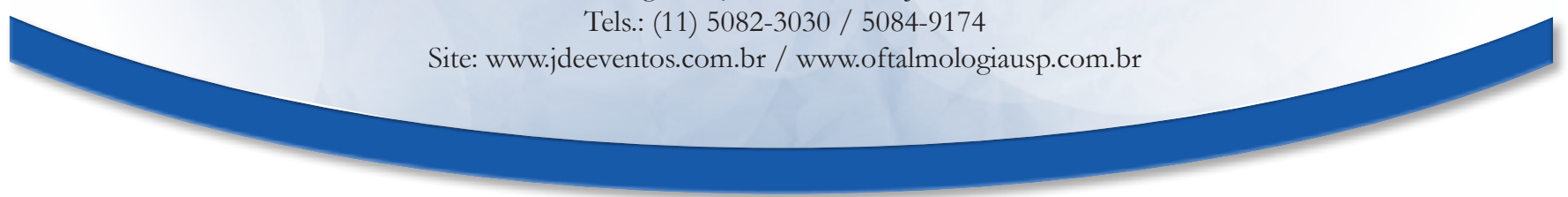

